\title{
Ecological restoration of degraded pasture lands in the Circum-Caspian Sea semi-desert
}

\author{
Nariman Shamsutdinov ${ }^{1, *}$, Musa Shagaipov ${ }^{1}$, and Vadim Sanzheev ${ }^{2}$ \\ ${ }^{1}$ All-Russian Research Institute for Hydraulic Engineering and Land Reclamation, 127550 Moscow, \\ Russia \\ ${ }^{2}$ Federal Williams Research Center of Forage Production \& Agroecology, 141055 Moscow region, \\ Lobnya, Russia
}

\begin{abstract}
For the ecological restoration of desert lands, the dominant species of fodder plants of the natural flora of the violent and patient ecology were used: Krascheninnikovia ceratoides (L.) Gueldenst., Bassia prostrata (L.) A.J. Scott, Camphorosma lessingii Litv., Artemisia lerhiana L., A. pauciflora Web., Poa bulbosa L. in various quantitative ratios in mixtures. Polydominant pasture ecosystems occupy different tiers of height in the aboveground sphere: semi-shrubs - up to $120-140 \mathrm{~cm}$, dwarf semi-shrubs - up to $45-75 \mathrm{~cm}$, ephemeroid grasses - up to $15-25 \mathrm{~cm}$. This ensures efficient placement of the leaf apparatus for efficient photosynthesis. In the underground sphere, various life forms of fodder plants form root systems and develop various ecological niches for more efficient use of water and mineral resources of a large volume of soil. Polydominant pasture ecosystems, which include various plant life forms, provide higher feed production, which exceeds the production of natural pastures by $3-5$ times.
\end{abstract}

\section{Introduction}

The problem of accelerated restoration of lost zonal biodiversity and biological productivity of desert pasture lands in arid areas of the Circum-Caspian Sea semi-desert is one of the primary tasks of modern science and practice. In a semi-desert zone with a severe xerothermic regime and a chronic lack of moisture, the recovery succession proceeds for a longer time. Does science have theoretical prerequisites and technical capabilities to accelerate the recovery succession on desert lands that have lost their natural vegetation?

At this time, the understanding of succession as a replacement of ruderal plants for communities consisting of plants of a violent and patient adaptive strategy with rational differentiation and packaging of ecological niches has been formed [1-4]. In this context, it is quite logical to assume the possibility of accelerated restoration of basic semi-desert vegetation on desert pasture lands on the basis of seeding zonally typical dominant plant species of natural

\footnotetext{
${ }^{*}$ Corresponding author: nariman@vniigim.ru
} 
(wild) flora, endowed with the properties of a violent (C-species) and a patient (S-species) adaptive strategy.

The objective of the work is to provide a biogeocenotic justification for ecological restoration of desert pasture lands in the Circum-Caspian Sea semi-desert based on seeding zonally typical species of fodder semi-shrubs, dwarf semi-shrubs, ephemeroid grasses of wild flora.

\section{Materials and methods}

For this purpose, field experiments were conducted in the semi-desert zone of the Yashkul district of the Republic of Kalmykia with the participation of zonal typical semi-shrubs and dwarf semi-shrubs of xerogalophytic plants of the violent and patient adaptive strategy in various ratios: Bassia prostrata (L.) A.J. Scott, Camphorosma lessingii Litv. Artemisia lerhiana L., A. pauciflora Web., Krascheninnikovia ceratoides (L.) Gueldenst. in three versions.

Determination of the number and survival of seedlings and adult plants, determination of plant height and yield were carried out according to the generally accepted methods of the AllRussian Research Institute of Feed n.a. Williams [5, 6].

Climate diagram of the study site location is shown in Fig. 1.

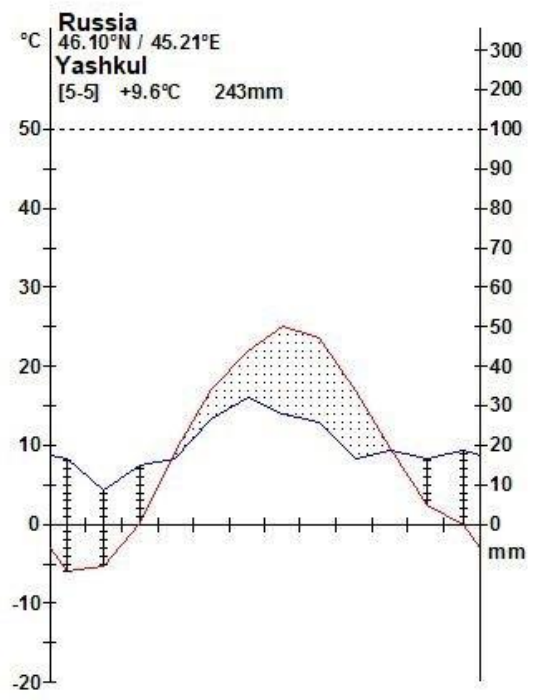

Fig. 1. Climate diagram of the study site location (meteorological station Yashkul)

The main background of the experimental site is represented by brown soils with $5-10 \%$ of the area of alkali soil spots, underlain by sandy loams, as well as yellow and brown loams. The level of groundwater is in the range of $15-20 \mathrm{~m}$. Soil salinity is chloride, the degree of salinity increases horizontally from $0.14 \%$ to $1.67 \%$.

\section{Results and discussion}

In all variants of the experiment, normal shoots were obtained. Satisfactory growth and development of the sown plant species was observed. 
In the second year of life, the best survival rates were characterized by Bassia prostrata $22.4 \%$, in the second version of the experiment, 20370 species per 1 ha were preserved by the end of the growing season. The survival rate of Camphorosma lessingii plants was $24.8 \%$ $(20,740$ species/ha). The best variant in the second variant of the experiment in Krascheninnikovia ceratoides - 36.7\% (11,851 species), in A pauciflora - $93.3 \%(5,185$ species per $1 \mathrm{ha}$ ) (table 1).

Table 1. Dynamics of plant abundance and survival in polydominant pasture ecosystems (Bassia prostrata + Camphorosma lessingii + Krascheninnikovia ceratoides + Artemisia pauciflora + Artemisia lerhiana)

\begin{tabular}{|c|c|c|c|c|c|c|c|c|c|c|c|c|}
\hline \multirow{3}{*}{$\begin{array}{c}\text { Plant name } \\
\text { as a part } \\
\text { multi-species ecosystems }\end{array}$} & \multicolumn{6}{|c|}{ 1st (2019) } & \multicolumn{6}{|c|}{ 2nd (2000) } \\
\hline & \multicolumn{2}{|c|}{ Spring } & \multicolumn{2}{|c|}{ Summer } & \multicolumn{2}{|c|}{ Autumn } & \multicolumn{2}{|c|}{ Spring } & \multicolumn{2}{|c|}{ Summer } & \multicolumn{2}{|c|}{ Autumn } \\
\hline & $\begin{array}{c}\text { plant } \\
\text { qty } \\
\text { thous } \\
\text { and } \\
\text { pieces } \\
/ 1 \text { ha }\end{array}$ & $\%$ & $\begin{array}{c}\text { plant } \\
\text { qty } \\
\text { thous } \\
\text { and } \\
\text { pieces } \\
/ 1 \text { ha }\end{array}$ & $\%$ & $\begin{array}{c}\text { plant } \\
\text { qty } \\
\text { thous } \\
\text { and } \\
\text { pieces } \\
/ 1 \text { ha }\end{array}$ & $\%$ & $\begin{array}{c}\text { plant } \\
\text { qty } \\
\text { thous } \\
\text { and } \\
\text { pieces } \\
/ 1 \text { ha }\end{array}$ & $\%$ & $\begin{array}{c}\text { plant } \\
\text { qty } \\
\text { thous } \\
\text { and } \\
\text { pieces } \\
/ 1 \text { ha }\end{array}$ & $\%$ & \begin{tabular}{|c} 
plant \\
qty \\
thous \\
and \\
pieces \\
$/ 1$ ha \\
\end{tabular} & $\%$ \\
\hline \multicolumn{13}{|c|}{ Variant I } \\
\hline Bassia prostrata & 90.0 & 100 & 27.0 & 30 & 25.0 & 27.7 & 12.8 & 14.2 & 12.8 & 14.2 & \begin{tabular}{|l|}
12.7 \\
\end{tabular} & 14.1 \\
\hline Camphorosma lessingii & 55.9 & 100 & 17.0 & 30.5 & 16.7 & 26.8 & 14.8 & 26.5 & 13.7 & 24.5 & $\mid 13.7$ & 24.5 \\
\hline Artemisia pauciflora & 8.1 & 100 & 3.0 & 36.4 & 1.9 & 22.7 & 1.9 & 22.7 & 1.9 & 22.7 & 1.9 & 22.7 \\
\hline $\begin{array}{c}\text { Krascheninnikovia } \\
\text { ceratoides }\end{array}$ & 32.6 & 100 & 18.5 & 57.4 & 13.0 & 40.1 & 12.2 & 37.8 & 12.2 & 37.8 & 11.9 & 36.7 \\
\hline Total & 186.7 & 100 & 65.5 & 38.6 & 56.5 & 29.3 & 41.7 & 25.3 & 40.6 & 24.8 & 40.1 & 24.5 \\
\hline \multicolumn{13}{|c|}{ Variant II } \\
\hline Bassia $_{1}$ & 157.4 & 100 & 29.3 & 20.4 & 27.8 & 19.4 & 25.9 & 18.1 & 25.2 & 17.6 & 25.2 & 17.6 \\
\hline Camphoros & 108.1 & 100 & 30.7 & 30.7 & 30.0 & 30 & 26.7 & 26.6 & 25.6 & 25.5 & 23.3 & 23.3 \\
\hline Artemisia lerhiana & 5.6 & 100 & 5.6 & 100 & 5.6 & 100 & 5.2 & 93.3 & 5.2 & 93.3 & 5.2 & 93.3 \\
\hline $\begin{array}{c}\text { Krascheninnikovia } \\
\text { ceratoides }\end{array}$ & 50.7 & 100 & 1.2 & 24.4 & 10.7 & 21.4 & 8.1 & 16.2 & 7.4 & 14.8 & 7.4 & 14.8 \\
\hline Total & 321.9 & 100 & 77.8 & 43.9 & 74.1 & 42.7 & 65.9 & 38.6 & 63.3 & 37.8 & 61.1 & 37.3 \\
\hline \multicolumn{13}{|c|}{ Variant III } \\
\hline Bassia prostrata & 91.9 & 100 & 16.7 & 18.3 & 15.6 & 17.1 & 20.0 & 22 & 20.4 & 22.4 & \begin{tabular}{|l|}
20.4 \\
\end{tabular} & 22.4 \\
\hline Camphorosma lessingii & 89.6 & 100 & 30.4 & 36.4 & 29.3 & 35.1 & 22.2 & 26.6 & 20.7 & 24.8 & 20.7 & 24.8 \\
\hline Artemisia lerhiana & 10.4 & 100 & 1.5 & 14.3 & 1.1 & 10.7 & 3.7 & 35.9 & 4.8 & 46.6 & 4.8 & 46.6 \\
\hline $\begin{array}{c}\text { Krascheninnikovia } \\
\text { ceratoides }\end{array}$ & 68.1 & 100 & 21.9 & 32.7 & 21.5 & 32.2 & 6.3 & 9.4 & 6.3 & 9.4 & 4.4 & 6.6 \\
\hline Total & 260.0 & 100 & 70.4 & 25.4 & 67.4 & 23.8 & 52.2 & 23.5 & 52.2 & 25.8 & 50.4 & 25.1 \\
\hline
\end{tabular}

The obtained data give grounds to speak about a fairly high feed productivity of polydominant semi-shrub and dwarf semi-shrub ecosystems in the xerothermal conditions of the Circum-Caspian Sea semi-desert. In the first year of vegetation, the communities formed from 2.03 to $3.15 \mathrm{t} / \mathrm{ha}$, in the second - from 2.29 to $3.6 \mathrm{t} / \mathrm{ha}$ of dry fodder mass. The most highperformance components were Bassia prostrata and Camphorosma lessingii (table 2).

Table 2. Feed productivity of polydominant dwarf semi-shrub pasture ecosystems in the Circum-Caspian Sea semi-desert, $\mathrm{t} / \mathrm{ha}$

\begin{tabular}{|c|c|c|c|c|}
\hline \multirow{2}{*}{$\begin{array}{c}\text { Plant name as a part of } \\
\text { multi-species agrophytocenoses }\end{array}$} & 1st (2019) & \multicolumn{3}{|c|}{ 2nd (2020) } \\
\hline & $\begin{array}{c}\text { Autumn } \\
(15 . I X)\end{array}$ & $\begin{array}{l}\text { Spring } \\
(20 . V)\end{array}$ & $\begin{array}{l}\text { Summer } \\
(27 . V I I)\end{array}$ & $\begin{array}{l}\text { Autumn } \\
\text { (09.IX) }\end{array}$ \\
\hline \multicolumn{5}{|c|}{ Variant I } \\
\hline Bassia prostrata & 1.05 & 0.65 & 1.06 & 1.08 \\
\hline
\end{tabular}




\begin{tabular}{|c|c|c|c|c|}
\hline Camphorosma lessingii & 0.1 & 0.13 & 0.11 & 0.24 \\
\hline Krascheninnikovia ceratoides & 0.1 & 0.13 & 0.11 & 0.26 \\
\hline Artemisia pauciflora & 0.78 & 0.51 & 0.66 & 0.71 \\
\hline Total & 2.03 & 1.43 & 1.94 & 2.29 \\
\hline \multicolumn{5}{|c|}{ Varian II } \\
\hline Bassia prostrata & 1.5 & 0.83 & 0.65 & 1.06 \\
\hline Camphorosma lessingii & 0.54 & 0.63 & 0.58 & 1.47 \\
\hline Krascheninnikovia ceratoides & 0.78 & 0.82 & 0.51 & 0.66 \\
\hline Artemisia lerhiana & 0.2 & 0.26 & 0.14 & 0.13 \\
\hline Total & 3.02 & 2.54 & 1.89 & 3.32 \\
\hline \multicolumn{7}{|l|}{ Varian III } \\
\hline Bassia prostrata & 1.54 & 0.9 & 0.69 & 1.16 \\
\hline Kamphorosma lessingii & 0.58 & 0.68 & 0.67 & 1.57 \\
\hline Artemisia lerhiana & 0.81 & 0.93 & 0.58 & 0.74 \\
\hline Total & 0.22 & 0.27 & 0.15 & 0.13 \\
\hline
\end{tabular}

In the system of theoretical ecology, the concept of an ecological niche is of fundamental importance [7]. From the point of view of the ecological niche principle, the interaction of species in a particular habitat becomes clear.

Согласно существующего в настоящее время понятия экологической ниши фитоценоз понимается как многомерное пространство, в пределах которого виды растений эволюционируют, чтобы соответствовать своей экологической нише [8].

L.G. Ramensky [9] distinguished the principle of complementarity of plant species in the use of external niche resources. K.A. Kurkin [10] concretized this principle in plants as differentiation of ecological niches in the use of ecotope resources in the process of restoration succession of pasture ecosystems.

Polydominant pasture ecosystems formed on the site of desert natural lands occupy 0-120 cm in the aboveground (air) environment (the upper tier is Krascheninnikovia ceratoides), the second ecological niche is occupied by Bassia prostrata and Camphorosma lessingii. In the polydominant pasture semi-shrub and dwarf semi-shrub grassy ecosystem, the lower ecological niche was formed by the ephemeroid (Poa bulbosa) and ephemeras (Fig. 2). 


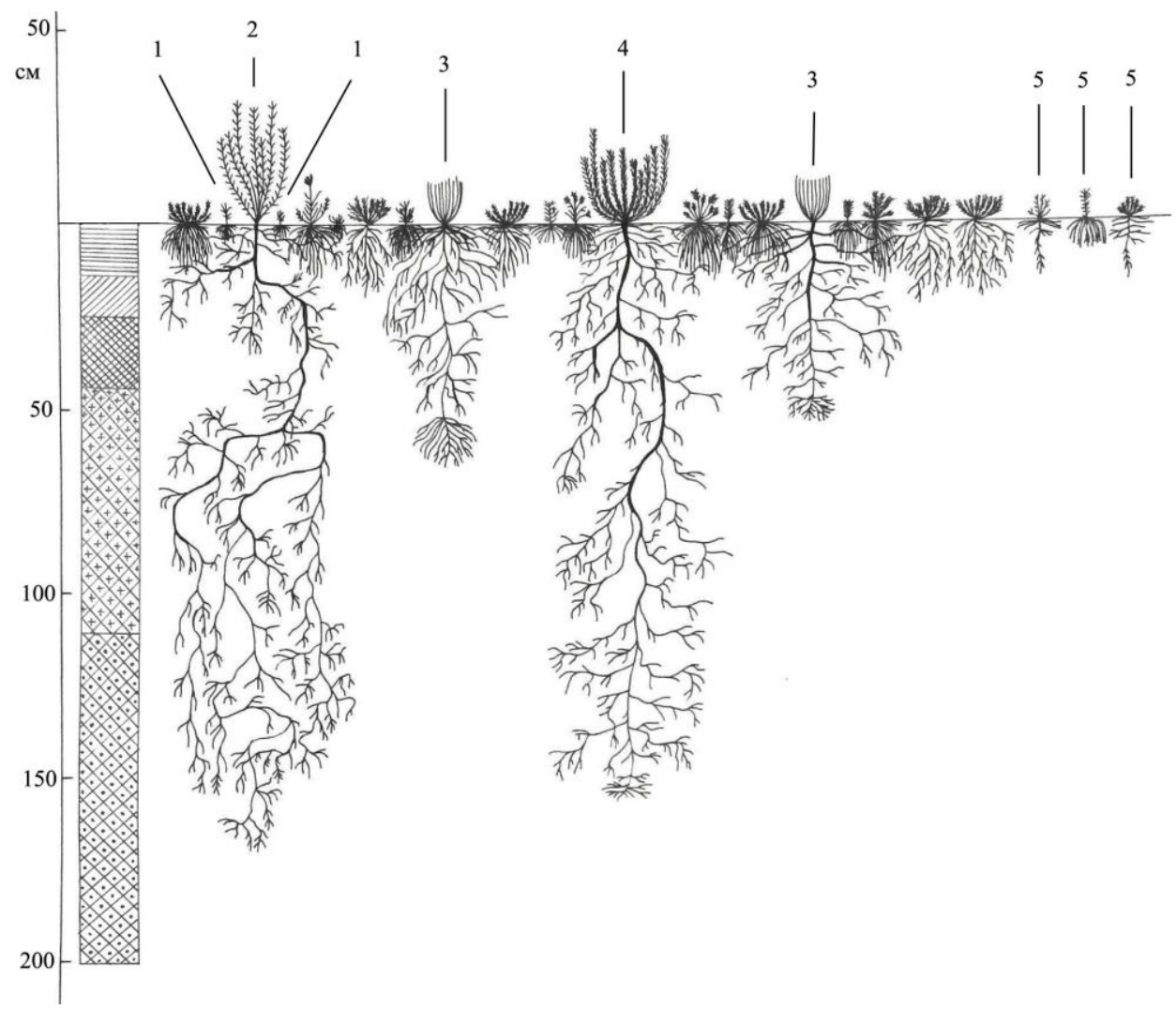

Fig. 2. Placement of plant root systems in polydominant semi-shrub and dwarf semi-shrub-herbaceous pasture ecosystems in the underground sphere at the age of two years in different ecological niches: 1 Poa bulbosa L., 2 - Krascheninnikovia ceratoides (L.) Gueldenst., 3 - Artemisia lerchiana Weber ex Stechm., 4 - Bassia prostrata (L.) A.J. Scott, 5 - ephemeras

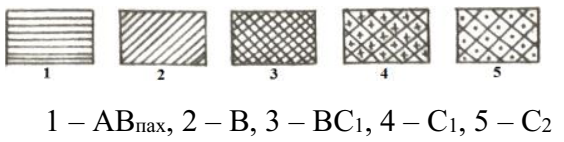

Seasonal complementarity of species is based on the use of fodder plants with long periods of growth and development. These include Krascheninnikovia ceratoides, Bassia prostrata, Camphorosma lessingii, Artemisia pauciflora, and Poa bulbosa - short growing plant.

All three variants of pasture ecosystems were formed with the participation of various fodder plant species: Bassia prostrata, Camphorosma lessingii, Krascheninnikovia ceratoides, Artemisia lerhiana, A. pauciflora with a growing season of 220-242 days, from the end of March to the beginning of December, which are in a green state before winter frosts. The ephemeroid plant Poa bulbosa and ephemeras with a short growing season from March to midApril is used the resources of the environment at different times. In other words, an ecological queue is being built in the use of the scarce water and mineral resources of the Circum-Caspian Sea semi-desert. The ability to occupy the maximum possible volume of the ecological niche of a pasture ecosystem with populations of the above plants in space and time ensures stable, maximum feed productivity. 


\section{Conclusions}

Polydominant pasture ecosystems, consisting of semi-shrubs, dwarf semi-shrubs and ephemeral herbs, occupy different tiers of height in the aboveground sphere: semi-shrubs - up to $120-140 \mathrm{~cm}$, dwarf semi-shrubs - up to $45-75 \mathrm{~cm}$, ephemeroid grasses - up to $15-25 \mathrm{~cm}$. This ensures efficient placement of the leaf apparatus for efficient photosynthesis. In the underground sphere, various life forms of fodder plants form root systems in different soil layers and develop various ecological niches for more efficient use of water and mineral resources of a large volume of soil. Multi-species pasture ecosystems consisting of various plant species and life forms best ensure the formation of increased feed productivity, which is 3-5 times higher than the productivity of natural pastures.

\section{Acknowledgment}

The project is supported by the RFBR (\#19-016-00185).

\section{References}

1. B.D. Campbell, J.P. Grime, An experimental test of plant strategy theory. Ecology, 73(1), 15-29 (1992)

2. J.P. Grime, Plants strategies and vegetation processes (Chichester etc.: Wiley, 1979)

3. J.P. Grime, Plant strategies. Vegetation processes and Ecosystem properties. 2 Edition. Chichester et al., (John Wiley and Sons, Ltd., 2001)

4. M. Westoby, Bioscience, 38(8), 549-556, (1988)

5. Methodical instructions on breeding and primary seed production of perennial grasses, (M.: All-Russian SRI of feed n.a. V.R. Williams,1993)

6. Z.Sh. Shamsutdinov, L.A. Nazaryuk, Yu.I. Ionis, A.A. Khamidov, N.N. Kozlov, S.V. Pilipko, E.Z. Shamsutdinova, V.P. Zvolinsky, V.I. Mukhortov, Tsagan-Mandzhiev N.L., B.A. Goldvarg, V.L. Aboyan, V.A. Paramonov, N.Z. Shamsutdinov, I.V. Savchenko, G.N. Bychkov, Guidelines for the mobilization of plant resources and the introduction of arid fodder plants (Moscow: RAAC, 2000)

7. E.P. Odum, Fundamentals of Ecology, Third Edition, W.B. Saunders Co. (Philadelphia, 1971)

8. G.E. Hutchinson, Concluding remarks. Cold Spring Harbour Symposium on Quantitative Biology, 22, 415-427 (1957)

9. A.G. Ramensky, Introduction to a comprehensive soil and geobotanical land survey (M., 1938)

10. K.A. Kurkin, Naturalists Society. Biol. Dep., 3(4) 3-14 (1983) 